\title{
Memory in the Aftermath of War: Australian Responses to the Vietnamese Refugee Crisis of 1975
}

Nathalie Huynh Chau Nguyen*

\begin{abstract}
This article interweaves the personal and archival by exploring the intersection of official Australian records on the fall of Saigon and government handling of Vietnamese refugees in 1975 with my family history. As transitional justice addresses the legacies of human rights violations including the displacement and resettlement of refugees in post-conflict contexts, Australian responses to the Vietnamese refugee crisis of 1975 provide a relevant case study. Drawing on a wide range of archival documentation at the National Archives of Australia and the National Library of Australia, including policy papers, Senate findings, confidential cables, ministerial submissions, private correspondence and photographs, I trace the effect of government decisions on Vietnamese refugees seeking asylum. In the process I reveal actions by senior bureaucrats and in particular by then Prime Minister Gough Whitlam that are largely unknown. Combining archival research with personal history enables me to not only shed light on past actions of governance and uncover past injustice but also explore the enduring impact of government decision-making on individual lives.
\end{abstract}

Keywords: Fall of Saigon, 1975, Vietnamese refugees, Australian government policy, political asylum, Vietnamese diaspora, National Archives of Australia, National Library of Australia

\section{Résumé}

Cet article conjugue le personnel et l'officiel en juxtaposant les archives officielles australiennes sur la chute de Saigon et sur le traitement des réfugiés vietnamiens par les autorités australiennes en 1975, d'une part, et l'histoire de ma propre famille, d’autre part. La justice transitionnelle traite des séquelles des violations des droits de la personne, y compris le déplacement et ré-établissement des réfugiés en

\footnotetext{
* The archival research at the National Library of Australia and the National Archives of Australia in Canberra was made possible by the award of a Harold White Fellowship from the National Library in 2007-2008. I first presented this material at my Harold White Fellow Public Lecture on "Vietnamese Refugees: Perspectives and Perceptions" at the National Library on 23 September 2008. Amended versions of the material were presented at the Australian Institute of International Affairs in Canberra on 27 October 2010, the Refugee Studies Centre at Oxford on 15 February 2011, and the Oxford Transitional Justice Seminar Series on 3 May 2011. My grateful thanks to Nicola Palmer, Julia Viebach, Briony Jones, and the anonymous reviewers for their comments and suggestions.
}

Canadian Journal of Law and Society / Revue Canadienne Droit et Société, 2015, Volume 30, no. 2, pp. 183-201. doi:10.1017/cls.2015.21 
contexte post-conflit; or, la réaction des autorités australiennes à la crise des réfugiés vietnamiens de 1975 en est un bon exemple. À partir d'une vaste gamme de documents archivés aux Archives nationales d'Australie et à la Bibliothèque nationale d'Australie, dont des mémoires de politiques, des études sénatoriales, des câbles confidentiels, des mémoires ministériels, de la correspondance privée et des photographies, je retrace l'effet des décisions gouvernementales sur les réfugiés vietnamiens demandant asile. Ce faisant, je mets en lumière des actions et gestes de hauts fonctionnaires, ainsi que du premier ministre de l'époque, Gough Whitlam, qui étaient jusqu'ici méconnus. En combinant mes recherches archivistiques à mon histoire personnelle, je peux non seulement mettre en lumière les actions passées des gouvernements successifs et les injustices commises, mais aussi retracer les effets durables des décisions gouvernementales sur la vie des personnes touchées.

Mots clés : Chute de Saigon, 1975, réfugiés vietnamiens, diaspora vietnamienne, politique gouvernementale australienne, asile politique, Archives nationales d'Australie, Bibliothèque nationale d'Australie

\section{Introduction}

This article explores the intersection of official Australian records on the fall of Saigon in 1975 and government handling of Vietnamese refugees with circumstances around my family's arrival in Australia as political refugees in 1975. My research demonstrates the potentially blurred categories of researcher and subject and illuminates the dynamic interplay between an official history of events and a deeply personal experience. The analysis of formal archives is paired with a reflective positionality that allows for a closer understanding of the personal dimension and consequences of past injustice. My parents were refugees from a communist state and sought asylum in a democratic state. As transitional justice addresses the legacies of human rights violations including the displacement and resettlement of refugees in post-conflict contexts, Australian responses to the Vietnamese refugee crisis in 1975 provide a relevant case study. "Since displacement and human rights violations are integrally linked," writes Roger Duthie, "transitional justice measures have reason to respond to displacement." Australian government responses to requests for asylum by Vietnamese refugees in 1975 provide the opportunity to examine the concept of asylum as a form of reparation for past injustice. ${ }^{2}$

The records in the National Archives of Australia and the National Library of Australia reflect the political atmosphere in Australia during the events of 1975 encompassing the collapse of South Vietnam, the end of the Vietnam War, and Australia's reception of Vietnamese refugees. While my parents arrived in Melbourne with their four young children in the winter of 1975, the archival record reveals that other Vietnamese who had sought asylum, including the staff of the Australian Embassy in Saigon, were refused entry. The archives reveal not only government

1 Roger Duthie, "Transitional Justice and Displacement," The International Journal of Transitional Justice 5 (2011): 243-44.

2 See James Souter, “Towards a Theory of Asylum as Reparation for Past Injustice," Political Studies 62 (2014): 326. 
actions at the time including those of Prime Minister Gough Whitlam ${ }^{3}$ but also the writings and assessments of senior bureaucrats. The methodological insertion of my family history alongside official records adds texture as well as a human dimension to the archival findings and enables a reading of the enduring impact of government decision-making on individual lives. These intersections led to discoveries in library archives that would not necessarily have emerged as a clear source of material on Vietnamese refugees. These explorations reveal the challenges of the research process and of transitional justice more broadly in that valuable material can be uncovered from sources that are not privileged. Together these provide a microcosm of events and illustrate the responses of senior figures in the Australian government and media to the moral dilemma presented by the Vietnamese refugee crisis of 1975.

Archival sources included government papers, policy documents, Senate findings, restricted cables between Canberra and Australian embassies overseas, ministerial submissions, private correspondence, and photographs. ${ }^{4}$ My task was to order and analyze this material and to construct a historical narrative from the available documentation. The archival record gave me the opportunity "to assemble the evidence to reflect on past actions of governance, where those actions continue to reverberate in society... a society open to the constant questioning of its actions, and its treatment of individuals and communities within its boundaries."5 Uncovering and ordering this past casts a new light on Australia's initial reception of Vietnamese refugees and allows for a deeper understanding of the ways in which the history of Vietnamese settlement in Australia, and more broadly, the reception of new refugee communities in Australia in the wake of conflict, can be interpreted and assessed.

\section{Historical Background}

The end of the Vietnam War in 1975 and Vietnam's reunification under a postwar communist regime triggered a major exodus. Its scale was unprecedented in Vietnamese history. The exodus followed widespread state repression in the former South, including the internment of more than a million people in re-education camps, ${ }^{6}$ the forced de-urbanization of another million to the New Economic Zones, ${ }^{7}$ the execution of 65,000 citizens, ${ }^{8}$ curtailment of individual and religious liberties,

Gough Whitlam (1916-2014) was prime minister of Australia in 1972-1975.

National Library of Australia: Oral histories of Vietnamese refugees collected in 1985-1986; the Denis Warner Papers; and Sir James Plimsoll Papers. NLA: ORAL TRC 2010; MS 9489; MS 8048. National Archives of Australia: Department of Foreign Affairs documents relating to Australian immigration policies and South Vietnamese political refugees; Australian policies and programs relating to Indochinese refugees and the staff at Republic of Vietnam embassies; and Australian representation in South Vietnam and the evacuation of Australian personnel from South Vietnam. NAA: A1838 1634/70/2 PART 2; A1838 1634/75/16 PART 1; A1838 3014/10/6/1 PART 2.

5 Terry Eastwood, "Reflections on the Goal of Archival Appraisal in Democratic Societies," Archivaria 54 (2002): 67.

6 United Nations High Commissioner for Refugees, The State of the World's Refugees: Fifty Years of Humanitarian Action (Oxford: Oxford University Press, 2000), 82.

7 Jacqueline Desbarats, "Human Rights: Two Steps Forward, One Step Backward?" in Vietnam Today: Assessing the New Trends, edited by Thai Quang Trung (New York: Crane Russak, A Member of the Taylor \& Francis group, 1990), 60.

8 Desbarats, "Human Rights," 63. 
nationalization of commerce and industry, ${ }^{9}$ and discrimination against all those associated with the former government as well as against ethnic Chinese and Amerasians. ${ }^{10}$ Over 700,000 people had fled the country by the middle of $1979 .{ }^{11}$ The plight of boat people ${ }^{12}$ received widespread recognition. The international community responded with "one of the longest-running migration and resettlement programs in the modern era," 13 encompassing two major United Nations conferences in 1979 and 1989, and stretching for twenty-five years from 1975 to the closure of the last refugee camp in Hong Kong in 2000. More than two million Vietnamese left their homeland in the two decades following the end of the war. The main countries of resettlement were the United States, Australia, Canada, and France; however Vietnamese communities were established in countries as diverse as Israel and Norway. The toll of this mass migration in terms of lives lost was immense and one of the great tragedies of this exodus is that the number of deaths will never truly be known. The losses of boat people are estimated at between 100,000 to a million in the postwar years. ${ }^{14}$ Postwar communist Vietnam was therefore characterized by widespread human rights violations including forced displacement, forced labour, internment without trial, and discrimination against individuals and families on political and ethnic grounds. ${ }^{15}$ These measures resulted in the disruption of social and familial networks in the former South as relatives disappeared in re-education camps, the New Economic Zones, or as escapees. The displacement of Vietnamese refugees as a consequence of state repression addresses central transitional justice concerns relating to the legacies of human rights abuses.

In Australia, the Vietnamese community grew from 1,000 in 1975 to approximately 233,000 in 2011 or just over one percent of the Australian population. ${ }^{16}$

9 See Desbarats, "Human Rights," 49-53; Linda Hitchcox, Vietnamese Refugees in Southeast Asian Camps (Basingstoke: Macmillan in association with St Antony’s College, 1990), 36-68; and James M. Freeman and Nguyen Dinh Huu, Voices from the Camps: Vietnamese Children Seeking Asylum (Seattle: University of Washington Press, 2003), 7-8.

10 See Desbarats, "Human Rights," 47-66; Hitchcox, Vietnamese Refugees, 44-68. For discrimination against Amerasians, see Kieu-Linh Caroline Valverde, "From Dust to Gold: the Vietnamese Amerasian Experience," in Racially Mixed People in America, edited by P.P. Maria Root (Newbury Park: Sage Publications, 1992), 144-61; Steven DeBonis, Children of the Enemy: Oral Histories of Vietnamese Amerasians and their Mothers (Jefferson: McFarland, 1995); and Robert S. McKelvey, The Dust of Life: America's Children Abandoned in Vietnam (Seattle: University of Washington Press, 1999).

11 W. Courtland Robinson, Terms of Refuge: The Indochinese Exodus and the International Response (London: Zed Books, 1998), 50.

12 The term "boat people" refers to Vietnamese refugees who fled Vietnam by boat in the postwar years. The great majority escaped their country by boat rather than by land. See, for example, Robinson, Terms of Refuge, 295.

13 United States Citizenship and Immigration Services, This Month in Immigration History: July 1979 (Washington: US Citizenship and Immigration Services, 2005), 1.

14 See Robinson, Terms of Refuge, 59; Hitchcox, Vietnamese Refugees, 11, 85; Nathalie Huynh Chau Nguyen, Voyage of Hope: Vietnamese Australian Women's Narratives (Altona: Common Ground Publishing, 2005), 15-17.

15 See Nguyen Van Canh, Vietnam Under Communism, 1975-1982 (Stanford: Hoover Institution Press, Stanford University, 1983); Desbarats, "Human Rights," 47-66; and Hitchcox, Vietnamese Refugees, 36-68.

16 Australian Bureau of Statistics, 2011 Census of Population and Housing Basic Community Profile: B13 Language Spoken at Home by Sex (Canberra: Commonwealth of Australia, 2012), B13 (b). 
There were three main waves of Vietnamese arrivals: the first, in 1975-1976, consisted of a small group of 539 well-educated refugees; ${ }^{17}$ the second included many ethnic Chinese escaping from Vietnam after the closure of private businesses in 1978 and the border war between Vietnam and China that same year, with numbers peaking at 12,915 in $1979-1980 ;{ }^{18}$ and the third consisted of so-called "economic refugees" ${ }^{\text {"19 }}$ with numbers peaking at 13,248 in 1990-1991. ${ }^{20}$ By 1996, a total of 150,000 Vietnamese had resettled in Australia. ${ }^{21}$ Vietnamese refugees formed the first and most difficult test case of the abolition of the White Australia policy, ${ }^{22}$ and "received exceptionally high attention in the media and in public discourse, particularly surrounding the debates on Asian immigration." 23

Under Liberal Prime Minister Malcolm Fraser, ${ }^{24}$ Australia responded generously to the Indochinese refugee crisis in 1978-1982 by accepting the largest number of refugees per head of population of all countries. ${ }^{25}$ The Vietnamese in Australia now constitute a well-established community. ${ }^{26}$ Fraser believed that Australia had an ethical obligation to take in Vietnamese refugees considering the scale of the humanitarian disaster after 1975. ${ }^{27}$ The moral function of asylum as a form of reparation, suggests James Souter, "stems from a special obligation on the part of states to provide asylum to refugees for whose lack of state protection they are responsible, whether through military intervention, support for oppressive regimes, or imposition of damaging economic policies." ${ }^{28}$ Under Labor Prime Minister Gough Whitlam in 1975 however, Australia deliberately restricted or prevented

17 Christine McMurray, Community Profiles 1996 Census: Viet Nam Born (Belconnen: Department of Immigration and Multicultural Affairs, 1999), 1.

18 Mandy Thomas, "The Vietnamese in Australia," in Asians in Australia: Patterns of Migration and Settlement, edited by James E. Coughlan and Deborah J. McNamara (South Melbourne: Macmillan Education Australia, 1997), 275.

19 Nancy Viviani, The Indochinese in Australia: From Burnt Boats to Barbecues (Melbourne: Oxford University Press, 1996), 104.

20 Thomas, "Vietnamese in Australia," 275. From the mid-1990s, the number of Vietnamese arriving in Australia as refugees declined with most Vietnamese arriving under family reunion. See Australian Government Department of Immigration and Citizenship, Community Information Summary: Viet Nam-born (Canberra: Australian Government Publishing Service, 2011).

21 McMurray, Community Profiles, 3.

22 Viviani, Indochinese in Australia, 1. The White Australia Policy consisted of a set of policies favouring immigration to Australia from certain European countries, in particular Britain. The policy was in effect from 1901 until 1973 although it was gradually dismantled by successive governments from 1949.

23 Thomas, "Vietnamese in Australia," 275

24 Malcolm Fraser (1930-2015) was prime minister of Australia in 1975-1983.

25 Jamie Mackie, “The Politics of Asian Immigration," in Asians in Australia: Patterns of Migration and Settlement, edited by James E. Coughlan and Deborah J. McNamara (South Melbourne: Macmillan Education Australia, 1997), 28.

26 See Viviani, Indochinese in Australia; Mandy Thomas, Dreams in the Shadows: VietnameseAustralian Lives in Transition (St. Leonards: Allen \& Unwin, 1999); Nathalie Huynh Chau Nguyen, Voyage of Hope: Vietnamese Australian Women's Narratives (Altona: Common Ground Publishing, 2005); and Nathalie Huynh Chau Nguyen, Memory is Another Country: Women of the Vietnamese Diaspora (Santa Barbara: Praeger, 2009).

27 Malcolm Fraser, Interview by George Megalogenis in "Malcolm Fraser: Life Wasn't Meant To Be Easy," a memorial tribute broadcast on ABC television on 22 March 2015.

28 Souter, "Towards a Theory of Asylum," 326. 
the entry of Vietnamese refugees. Such a historical analysis reveals that offering asylum as a form of reparation is time sensitive. It often requires immediate action in the wake of conflict.

It is against this background that I focus on the reactions of senior Australian figures to the end of the Vietnam War and the ensuing refugee crisis: the first is Denis Warner, a well-known journalist and author; the second is Geoffrey Price, the last Australian ambassador to South Vietnam; and the third is Sir James Plimsoll who was, in 1975, the Australian ambassador to the Soviet Union. All were responding to the Australian government's reactions to events in Vietnam and the growing number of refugees from South Vietnam.

\section{Australian Perspectives: The Papers of Denis Warner}

Denis Warner was Southeast Asian correspondent for the Reporter, editor of the Asia Pacific Defence Reporter, and the author of several books including The Last Confucian (1963) and Disaster in the Pacific (1992). He left Saigon on 25 April 1975, five days before the city fell, on the last Australian plane with Ambassador Price. Warner notes in his memoir that he left "with immense sadness [and] with tears in [his] eyes." ${ }^{29}$ Warner's papers contain a vast amount of material on Vietnam. He wrote letters of reference for individual Vietnamese and contacted international organizations such as the United Nations High Commissioner for Refugees to ask for information about the missing relatives of refugees. Among Warner's papers, the letters he received from Australians who were touched by the plight of the refugees were particularly compelling.

The following extract is from one such letter. It is from Margaret Grouse, whose husband was an academic at the University of New South Wales. Her letter is dated 6 April 1976 and concerns the thirty-five married Vietnamese students in Australia who tried to bring their families over. Two of these students were in New College, where her husband was Dean. She writes:

It was not until late on April 21st, after much public agitation, that the Prime Minister agreed that dependents should be allowed to join their spouses... Names were telexed from the Department of Foreign Affairs... to the Australian Embassy in Saigon. For some reason, some of the wives who managed to argue their way into the embassy were told that their names were not on the list. None was given an Australian entry visa or any kind of evacuation assistance... We know of only 5 spouses who managed to reach Australia-4 somehow got on the American airlift, one received assistance from the German pharmaceutical firm which employed her. There are still about 30 wives and 50 children in Saigon (if still alive). Tragically, the P.M.'s announcement on the 21st caused many wives to receive cables from their husbands telling them that the Australian Embassy planned to help evacuate them. Letters, which were flown back to Australia right up until the last moment, tell how some wives abandoned, as a consequence, their plans of reaching a boat at the coast. One refused assistance

29 Denis Warner, Not Always on Horseback: An Australian Correspondent at War and Peace in Asia 1961-1993 (St. Leonards: Allen \& Unwin, 1997), 220. 
from an American family believing she was to be flown direct to Australia. The letters are heartbreaking.

When we realised that the families of students had been abandoned, Roger Fordham...a former Adelaide schoolteacher then working for A.S.I.A.C. [Australian Society for Intercountry Aid Children], with his knowledge of Saigon, a current passport and much courage, took off on 27th April on a commercial flight with lists of names and addresses, in the hope of getting these folk on to the American airlift. He was offloaded at Manila and was unable to proceed further. Later, both Roger and my husband Phil, went to Guam looking for student relatives... (They found no wives but about 100 parents or brothers or sisters of Vietnamese in Australia; practically all were refused entry by the former P.M....)

On June 5, a group of us...flew from Sydney to Canberra and lobbied all day in King's Hall...Sen. Withers was most helpful and on June 11 got the Sen. Select Committee on Foreign Affairs and Defence set up...By the way, Whitlam refused to see us then, and on all previous and subsequent occasions. ${ }^{30}$

This letter is cited at length because it provides a vivid portrayal of the chaos surrounding the last days of Saigon in April 1975 and demonstrates the extent to which individual Australians - in this case, a small group of concerned academics and academics' wives - went in their efforts to assist Vietnamese refugees.

Warner's papers contain his detailed statement to the Senate Standing Committee on Foreign Affairs and Defence on the issue of Vietnamese refugees. He appeared before the Committee on 13 October 1975. Two points in his statement stand out. The first is that Australia evacuated only one Vietnamese staff member from the Australian Embassy in Saigon. Warner states,

With only one exception, the Australian government declined to authorise the evacuation of Vietnamese working for the Embassy. The local employees maintained their posts loyally to the last minute, and when the Embassy evacuated on April 25 its books were up-to-date as of 6 p.m. on April 24. They had been prepared by a woman whose own life was thought to be endangered and whose application for evacuation had been rejected by Canberra. ${ }^{31}$

The second is that Australia did not help any of the Vietnamese who had worked closely with the Australian Army.

During the period that the Task Force was in Vietnam, nearly 50,000 Australian soldiers passed through Phuoc Tuy province. Their security depended not only on their own efforts but on the loyal co-operation of the people of Phuoc Tuy. This was freely given and the relationship between the people of the province and the Task Force was exemplary. Scores of officials, ranging from province chiefs down to village and hamlet administrators, worked closely with the Australians. In gratitude for the Australian effort the people of Phuoc Tuy 
erected a memorial to the Australian forces outside the provincial capital of Baria and there were plans to build an Australian-Vietnamese library and museum next to the war memorial. Either the Australian Government was entirely ignorant of the fate that would overtake many of these officials, or it did not care, since no attempt was made to ascertain the wishes of any people in Phuoc Tuy and no attempt was made to help any to escape. ${ }^{32}$

He continues:

It is my very strongly held view that the Australian Government, whether we were right or wrong by being in Vietnam, inherited a residual responsibility, not to mention a moral responsibility, to assist in the evacuation from Vietnam of those who had assisted our forces there and whose lives they believed to be in danger because of this assistance. ${ }^{33}$

The issue here is that of loyalty. Warner believed that Australia should have repaid loyalty with loyalty. Of the prime minister's role in all of this, Warner's submission reads:

I have been told repeatedly by officials that Mr Whitlam accepted personal responsibility for the admission, or otherwise, of all Vietnamese refugees wanting to come to Australia. I was told by one official that Mr Whitlam was quite unsympathetic. ${ }^{34}$ "These Vietnamese sob stories don't wring my withers," he is reported to have said. Mr Whitlam is also on record that there would be no reprisals in Vietnam and is privately said to hold the view that it would be better if the refugees returned there. ${ }^{35}$

Warner's statement underlines his concerns regarding those who had worked closely with Australian forces in South Vietnam. He knew that they would be at particular risk from the incoming communist regime-a belief that was borne out by the postwar internment of more than a million former soldiers, public servants, and teachers in re-education camps. Warner's representation to the Committee links to Souter's theory regarding the provision of sanctuary as a means of reparation. Warner believed that Australia had a moral obligation to evacuate the Vietnamese staff of the Australian Embassy as well as all those who had assisted Australian troops during the war. "Asylum should be conceived not only as playing a 'palliative' humanitarian role or expressing condemnation," writes Souter, "but also as potentially providing a means by which states can rectify the harm they caused to individuals by turning them into refugees." 36 Warner's statement aligns closely with Souter's argument regarding the reparative role of asylum.

\section{The Fall of Saigon: Difficult Choices}

Saigon fell to North Vietnamese forces on 30 April 1975. The city's collapse led to the first wave of refugees from South Vietnam. In Australia, the Report of the Senate

Ibid.

NLA MS 9489/1/79: 257.

"[W]hen Barnard and I wanted to send aircraft to bring babies and orphan children from Saigon to Australia in April of 1975, [Gough] cancelled the flight and declared he didn't want any 'Vietnamese Balts coming into Australia." Clyde Cameron, The Cameron Diaries (Sydney: Allen \& Unwin, 1990), 801. Cameron was minister for labour in 1972-1974 and minister for labour and immigration in 1974-1975.

35 NLA MS 9489/1/79: 246.

36 Souter, “Towards a Theory of Asylum," 326. 
Standing Committee on Foreign Affairs and Defence on the issue of Vietnamese refugees was published in 1976. The report was highly critical of the Australian government's actions. Five of its findings were notable: first, it referred to the difficulty of obtaining accurate information and to conflicting and incomplete evidence provided by government departments, voluntary organizations, and individuals; ${ }^{37}$ second, the admission criteria for Vietnamese refugees were announced too late on 22 April $1975 ;^{38}$ third, every decision was centralized in Canberra, and this impeded the work of the Australian Embassy in Saigon; ${ }^{39}$ fourth, only one Vietnamese member of staff was evacuated (with his wife and child); ${ }^{40}$ and last, the Australian government had a moral obligation to assist in the evacuation of Vietnamese but had deliberately delayed in order to minimize the number of refugees Australia would have to contend with. ${ }^{41}$

Official records on the fall of Saigon that were released after the end of their thirty-year embargo not only confirm these findings but also provide considerable additional detail. The documents include secret cables that were sent between Canberra and the Australian Embassy in Saigon and confidential ministerial submissions relating to Vietnamese refugees.

Geoffrey Price, the Australian ambassador to South Vietnam, cabled Canberra on 20 April 1975:

Intelligence estimates state that by the end of today or tomorrow a total of seventeen NVA [North Vietnamese Army] divisions which are relatively well-equipped and well-supplied will constitute the force that is to take Saigon. This massive NVA force will outnumber the ARVN [Army of the Republic of Vietnam] by close to three to one and their anti-aircraft defence capability will probably largely nullify the RVN [Republic of Vietnam]'s possession of an aerial strike force. ${ }^{42}$

And further on,

\section{Locally Engaged Staff (Underline Three)}

The fate of our locally engaged staff together with relatives of wives married to Embassy officers is causing us all much distress. I am afraid that you must take the decision on this taking into account the likelihood that we could encounter problems with the local authorities. At the same time, I should like discretion to include any who can be included legally... ${ }^{43}$

Canberra cabled back on 21 April:

Ministers have decided that:

(A) Having regard to the principle of family unity the wives and children of Vietnamese students at present in Australia should be permitted to enter Australia.

\footnotetext{
37 Senate Standing Committee on Foreign Affairs and Defence. Report: Australia and the Refugee Problem: The Plight and Circumstances of Vietnamese and Other Refugees (Canberra: Australian Government Publishing Service, 1976), preface.

38 Senate, Report, 18

39 Ibid., 20.

40 Ibid., 24

41 Ibid.

42 NAA A1838 3014/10/6/1 PART 2: 108

43 NAA A1838 3014/10/6/1 PART 2: 109.
} 
(B) Passport [sic] are to be issued to the spouses and the children under twentyone of Australian citizens following completion of citizenship formalities... this will qualify them for evacuation.

(C) Locally engaged Embassy Staff are not to be regarded as endangered by their Australian Embassy associations and therefore should not repeat should not be granted entry into Australia.

(D) If any Vietnamese with long associations with Australia is regarded by you as being in grave danger you may refer the case to Canberra for consideration on an exceptional basis. Ministers however would not expect more than a handful of such cases for consideration and you should not stimulate expectations in this context. ${ }^{44}$

It should be noted that there were approximately 350 Vietnamese students in Australia at the time, and that the great majority of these were unmarried and childless. Phan Dong Bich, for example, who was a Colombo Plan student in Sydney in 1975, said that students were frantic about their families in Vietnam and organized demonstrations, petitions, and hunger strikes. "Family" for these students meant parents and siblings, but these fell completely outside the criteria set by the Australian government.

Peter Edwards was right to note that Ambassador Price was "caught between horrific political and moral pressures, while he and his staff struggled to operate in a capital facing imminent defeat and while he tried to comply with instructions from Canberra that in many cases he thought were shameful, contradictory or impossible of achievement." ${ }^{46}$ Like Warner, Price was fully cognizant of the fact that the Vietnamese staff of the Australian Embassy would be targets for communist reprisals after the fall of Saigon. As head of mission, he had a moral obligation to protect his staff (whether Australian or Vietnamese). The Australian government bore direct responsibility for the fate of locally engaged staff working in one of its missions overseas. However, as the cable of 21 April 1975 reveals, Canberra specifically ordered Price not to admit any Vietnamese embassy staff to Australia. Price's son Christopher published a letter to this effect in The Australian in 2005:

My father, as Australia's ambassador, was obeying direct and specific instructions from the Australian government, which he had bitterly but unsuccessfully disputed over the preceding days, in not evacuating the Australian embassy's 55 Vietnamese staff on the RAAF Hercules sent to evacuate the other few remaining Australian staff and him...

In an article The Australian ran on the 25th anniversary of the fall of Saigon in April, 2000, Stuart Rintoul reported my father's enduring sense of shame at the way Australia abandoned all but one of its locally engaged Vietnamese embassy staff, together with many other Vietnamese at risk of being punished by the incoming North Vietnamese for their associations with Australia. I can confirm that my father's shame at Australia's petty betrayal

$44 \quad$ NAA A1838 1634/70/2 PART 2: 244.

45 Phan Dong Bich, telephone conversation with the author on 17 November 2007.

46 Peter Edwards, "The Fall of Saigon, 1975," RG Neale Lecture Series (Canberra: The National Archives of Australia and the Department of Foreign Affairs and Trade, 1 May 2006), 13-14. 
of Vietnamese colleagues who had worked alongside him...did remain with him until the day he died. ${ }^{47}$

Geoffrey Price may have obeyed his government's instructions, but he was haunted by this decision for the rest of his life. It was clearly a matter of conscience for him.

\section{Vietnamese Refugees in 1975: The Archival Record and the Papers of Sir James Plimsoll}

The cables dealing with the fall of Saigon were distressing enough, but it was in another set of documents on policies relating to Indochinese refugees that I first saw my father's name and uncovered the following information on Prime Minister Gough Whitlam's actions. While Whitlam's lack of sympathy towards Vietnamese refugees in 1975 is well known, these papers reveal the extent to which he had a direct hand in refusing them entry. The documents show that Whitlam personally rejected Vietnamese refugee applications that had already been approved by his foreign minister, Don Willesee.

Whitlam's annotations appear in a confidential document entitled "Vietnamese Refugees: Applications by Former Vietnamese Diplomatic Staff, Now in Third Countries, to Enter Australia" containing two applications for entry approved by ministers, and fourteen applications approved by the foreign minister. ${ }^{48}$ Whitlam wrote "No" next to most names: an example of lives determined by a stroke of the pen. His handwritten annotations appear in blue on the left-hand margin. ${ }^{49} \mathrm{He}$ provides no explanations for his decisions. Out of fourteen refugee applications, Whitlam rejected eleven outright, wrote "Possible" for two, and "Not at present" for a third. My family was one of these two "Possibles." My father's is the last name on the first page:
Nguyen Trieu Dan, Ambassador, Tokyo, and family. Nguyen Trieu Dan and his wife are both graduates and might possibly qualify for approval under normal immigration policy. They do not have any direct association with Australia, but Ambassadors Plimsoll and Shann have commented very favourably on Dan and have urged acceptance. Shann believes that Dan would give a written undertaking not to engage in politics. Our Tokyo Embassy has reported that the Japanese Government is unlikely to allow the Vietnamese Embassy staff to remain in Japan. ${ }^{50}$

It appears that Whitlam put "Possible" because of those favourable comments by Plimsoll and Shann-he underlined those sentences. However, this "Possible" was conditional on my father signing a special undertaking. A later document dated 11 June 1975 by K. H. Rogers ${ }^{51}$ states:

When you considered our submission of 28 May on this subject...you indicated that the former South Vietnamese ambassador to Japan and the former Third Secretary of the South Vietnamese Embassy in Kuala Lumpur might

\footnotetext{
47 Christopher Price, "Last Days of Saigon Still Linger," The Australian, 4 May 2005, 14.

48 NAA A1838 1634/75/16 PART 1: 43-43, 70-72.

49 Ibid.

50 NAA A1838 1634/75/16 PART 1: 43, 70.

51 Rogers was first assistant secretary to the international organisations and protocol division.
} 
be approved for entry to Australia if they were prepared to give written undertakings not to engage in politics in Australia.

2. This condition has been put by our respective missions to Mr Dan and $\mathrm{Mr}$ Ban, and each has confirmed that he would be willing to give a written undertaking not to engage in or allow himself to be drawn into politics in Australia.

3. I should be grateful for your direction now as to whether Messrs. Dan and Ban may be granted entry into Australia for temporary residence.

4. I should be grateful to know also whether you have any further direction to give concerning the case of Mr Tran Van Ngo, First Secretary of the former South Vietnamese Embassy in Tokyo, against whose name you wrote "not at present" when you considered the previous submission. ${ }^{52}$

Whitlam's handwriting is visible in the margin: "Admit both" for my father and Mr. Ban, and "No" for Mr. Tran Van Ngo, initialed on 13 June $1975 .^{53}$ The original of my father's signed undertaking is also in the archives:

I, Nguyen Trieu DAN, undertake that if admitted to Australia I will not engage in, or allow myself to be drawn into, political activity in Australia. ${ }^{54}$

The irony of a democratic government insisting on this undertaking when he was a political refugee from a communist state did not escape my father. It was an added humiliation that he had to bear on top of the loss of his country, government, and career. My father stressed how grateful he was to the Fraser government that came to power at the end of 1975, because Michael MacKellar, the minister for immigration under Fraser, sent him a letter of apology in 1976, which states,

[T] he government considers it inappropriate for you to be required to sign that undertaking and...the government has decided that the undertaking will no longer be binding upon you. The document will be cancelled and your continued residency in Australia will be entirely unconditional in respect of its contents. ${ }^{55}$

In all, seven restricted cables dealt with my father. The cables also reveal that he had said that "his family would not become a charge on the state," and that he interceded on behalf of "those members of his former staff and...Vietnamese students in Japan who wanted to migrate to Australia." 56

As his daughter, I was privy to some of this history, but it is one thing to be told about past events, and quite another to see them recorded in such detail in the archives. The difference in these distinct ways of knowing my own past were illuminated starkly when the "formal" came face to face with the "personal."

NAA A1838 1634/75/16 PART 1: 38.

Ibid.

NAA A1838 1634/75/16 PART 1: 23. The undertaking was signed by my father on 17 June 1975. Excerpt of a letter from Michael MacKellar to Tran Van Lam dated 18 February 1976, as quoted in the Rymer Bayly Watson documentary film, All Points of the Compass, on ABC television, 1 May 2005. My father could not find his copy of MacKellar's letter, but it would have been similar to the one addressed to Tran Van Lam.

56 NAA A1838 1634/75/16 PART 1: 32. The cable is dated 6 May 1975, the day on which my father lodged a formal application for migration at the Australian Embassy in Tokyo. 
My father had conveyed that the process of seeking asylum in Australia had been difficult. The material in the archives not only confirms this but also goes considerably further. With the recognition of my father's name, his signature, and that list of "Nos" by Whitlam came the painful realization that our family almost did not become Australian - that Australia nearly rejected us and, in fact, did reject the other Vietnamese refugees whose names figure on that list. That one word, "Possible," was the factor that differentiated our trajectory from that of the other refugees on the list. Terry Eastwood suggests that archives can provide a "retrospective understanding of the actions of government [and] foster the recognition and identity of cultural communities." ${ }^{57}$ These archives reveal the actions of the Whitlam government and more specifically of Whitlam himself towards Vietnamese refugees in 1975. Vietnamese refugees whose applications for asylum were approved by Foreign Minister Don Willesee were then denied entry by Whitlam. "Without archives," suggest Joan Schwartz and Terry Cook, "memory falters...Archives counter these losses. Archives contain the evidence of what went before." ${ }^{58}$ Reading through these hundreds of pages of documents, I sought to reflect on the positive elements that could be drawn from the archival record.

First, I noted that senior public servants did their best in the face of the prime minister's obduracy. Those who prepared ministerial submissions presented Vietnamese applicants and their families in as positive a light as possible. In a submission dated 6 May 1975, H. Gilchrist, First Assistant Secretary to the Legal and Treaties Division, wrote:

Most of those listed above, as members of the foreign service of the former Saigon Government, would believe that they have cause, for political reasons, to fear for their personal safety if they are to return to Saigon. How far some of them at least actually do, or will, have such cause, can only be a matter of judgement. However, there appears to be sufficient cause to raise the question of territorial asylum for consideration. Some, but not all of the applicants have Australian connections. Their foreign service background would assist in their general adaptability to life during their stay in Australia, whether temporary or permanent. ${ }^{59}$

Second, I was touched by the cables Ambassadors Plimsoll and Shann sent on behalf of my family. Both were prominent senior diplomats-Shann had made his reputation in Indonesia in the $1960 \mathrm{~s}^{60}$ and was the Australian ambassador to Japan, while Plimsoll was then Australian ambassador to the Soviet Union. ${ }^{61}$ Plimsoll had met my father in India. He cabled Canberra on 3 May:

57 Eastwood, "Reflections on the Goal of Archival Appraisal," 59.

58 Joan M. Schwartz and Terry Cook, "Archives, Records, and Power: The Making of Modern Memory," Archival Science 2 (2002): 18.

59 NAA A1838 1634/75/16 PART 1: 49.

60 See Joan Beaumont, "The Champagne Trail? Australian Diplomats and Overseas Mission," in Ministers, Mandarins and Diplomats: Australian Foreign Policy Making 1941-1969, edited by Joan Beaumont, Christopher Walters, David Lowe with Garry Woodard (Carlton: Melbourne University Press, 2003), 183-85.

61 See Department of the Special Minister of State, Australian Government Directory 1975 (Canberra: Australian Government Publishing Service, 1975), 153, 155. 
I have received the following telegram from Tokyo from Nguyen Trieu Dan who until now has been Ambassador to Japan of the Republic of Viet-Nam.

Begins:

Following recent events in Viet-Nam would like to emigrate with my family to Australia. One member of my staff would also like to join us with his family. Would you agree to sponsor us? As Ambassador Shann is now in Canberra we cannot put our case to him. Hope you are keeping well and looking forward to hearing from you. Greetings and best regards.

Ends.

2. Dan was Consul-General of the Republic of Viet-Nam when I was in India. He was later with the negotiating team in Paris. I have had contact with him over the years and have seen him in Tokyo since he took up his post there. I regard him as a personal friend.

3. Dan and his wife are relatively young. They are intelligent and of good personality and character and speak good English. His wife is a graduate in economics of (if I remember correctly) the University of Cambridge.

4. I would like to do whatever I can to help them. I urge they be admitted to Australia. Is there anything I can do from here...

5. I am sure that Shann will endorse my high opinion of the Dans and if he is in Canberra you might like to consult him.

6. I have sent a message to Dan saying that I have supported his admission. ${ }^{62}$

Four days later, Shann cabled from Tokyo:

3. I want to add my own personal and earnest support to what Plimsoll has said in his message. I entirely endorse his high opinion of the Dans as I indicated both to the Acting Secretary and to Gilchrist in Canberra. Furthermore I am quite certain that Dan would give a written undertaking not to engage in political activity of any kind in Australia. If it is technically possible and if it would be of any help, I would be personally prepared to offer whatever sponsorship could be arranged.

4. Should you want a further opinion about Dan, I suggest you refer to Sir Arthur Tange, as they were both in Delhi at the same time. ${ }^{63}$

Sir Arthur Tange was at the time Secretary of the Department of Defence. ${ }^{64}$ Both Plimsoll and Shann cabled strongly worded endorsements of my father's application to Canberra, and it seems clear from the archival record that that was the only reason why Whitlam wrote "Possible" next to my father's name.

In the midst of this research, I discovered that the National Library held the papers of Sir James Plimsoll (1917-1987). The archival record led me to consult

See Department of the Special Minister of State, Australian Government Directory 1975, 115. 
manuscripts that I would not have examined otherwise. There was no obvious connection between Plimsoll and Vietnamese refugees-only the mention of one visit he made to Vietnam in 1967. I returned to the Manuscripts Collection and searched for traces of my parents amidst these papers. To my delight, I found several. The first was the following photograph of Plimsoll and my parents taken in New Delhi in $1964 .^{65}$

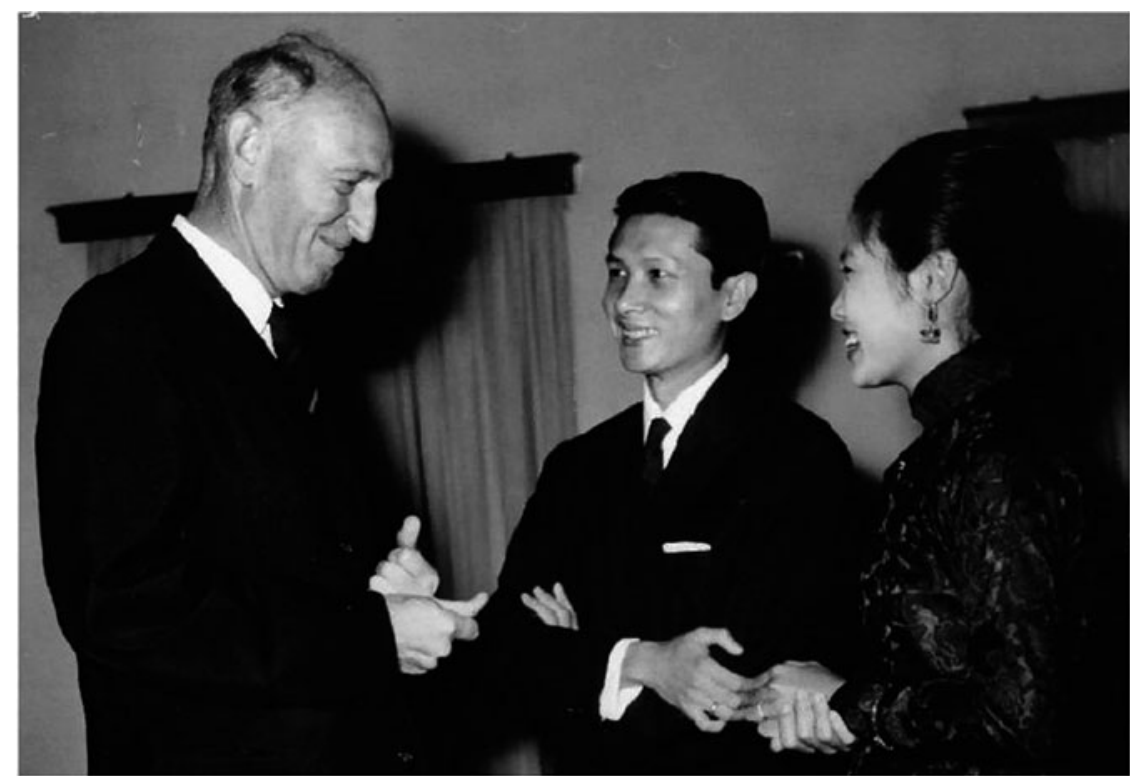

Sir James Plimsoll with Nguyen Trieu Dan and Huynh Bich Cam in New Delhi, 1964. NLA MS 8048/14/8.

In a separate folder, there was a letter from my father dated 27 November 1964, which makes a logical companion to the photograph:

Dear Sir James,

I have the honour to send you a photograph taken at "Vietnam House" on the occasion of the National Day of the Republic of Vietnam.

Hoping that you would like it.

I am

Yours sincerely,

Nguyen Trieu Dan

Acting Consul General ${ }^{66}$

My father was thirty-four at the time, and my mother not yet twenty-four. They had married in London after my mother's graduation from Cambridge in

66 Nguyen Trieu Dan to Sir James Plimsoll, 27 November 1964; NLA MS 8048/14/9. 
1962 and arrived in India at the end of 1963. Plimsoll is described in a recent study as

tall and balding, serious, studiously polite...As a workaholic, he quickly became indispensable... because of his orderliness, fine writing skills, calmness and capacity for complete loyalty...He became well known to Menzies, who relied on his drafting skills, capacious memory and judicious counsel. As a lifelong bachelor he was accessible for urgent tasks around the clock... Plimsoll added to his reputation as a diplomat in his next two posts, as permanent representative at the United Nations in New York from 1959 to 1963, and as High Commissioner in New Delhi, 1963-65. ${ }^{67}$

I went through Plimsoll's papers and diaries-many of which were partly burnt, with charred covers and pages following a fire at the Australian Embassy in Moscow in 1977-and found further references to my parents. He had extended invitations to them, and recorded receptions that he attended including the one at Vietnam House where the photograph was taken. He referred to my father by his full name and position (Plimsoll's diaries were appointment diaries-he did not record his thoughts or feelings). In his 1975 diary, during his Moscow appointment, he recorded on Friday 2 May:

14:00 I received a telegram from NGUYEN TRIEU DAN (the Ambassador in Tokyo of the Republic of Vietnam) saying that he and his family would like to migrate to Australia, and seeking my sponsor [sic]. ${ }^{68}$

I reviewed my notes and found that he had acted swiftly: he cabled Canberra on Saturday 3 May, the day after receiving my father's telegram. He was truly a good man, and I wish I could have met him to thank him. His last public appointment was as Governor of Tasmania, and he died in Hobart in 1987.

\section{Conclusion}

"Archives," note Schwartz and Cook, "wield power over the shape and direction of historical scholarship, collective memory, and national identity, over how we see ourselves as individuals, groups, and societies." 69 Archival documents provide evidence about past human rights violations and the means to gauge how these reverberate in the present. When these archives are supplemented by individual family histories, the resulting interplay of personal history with collective memory and official records provides a multilayered representation of past injustice.

The findings in the Australian archives provide not only a written record of the Australian government's handling of Vietnamese refugees in 1975, and in particular the actions of then Prime Minister Gough Whitlam, but also a documentary trail relating to my father's request for political refuge and the circumstances surrounding my family's arrival in Australia. They reveal that in 1975 the Whitlam government dismissed the dangers facing the Vietnamese staff of the Australian

\footnotetext{
67 Joan Beaumont, "Paul Hasluck: The Diplomat as Minister," in Ministers, Mandarins and Diplomats, edited by Beaumont et al., 143-44.

68 NLA MS 8048/3/27.

69 Joan M. Schwartz and Terry Cook, "Archives, Records, and Power: The Making of Modern Memory," Archival Science 2 (2002): 2.
} 
Embassy in Saigon and refused to grant them asylum in spite of the urgent requests of Ambassador Price, and that Whitlam subsequently had a direct hand in rejecting Vietnamese refugee applications even after these had been approved by one of his own ministers. The actions of the Whitlam government towards Vietnamese refugees in 1975 have distinctive transitional justice implications. Transitional justice seeks to redress the legacies of past human rights abuses. Australia had a moral responsibility to provide sanctuary to locally engaged staff at its embassy in South Vietnam, and an obligation to assist in the evacuation of all those who had assisted Australian troops in Phuoc Tuy province during the war, however it chose to rescind its responsibilities. The archives reveal that senior public servants and journalists sought to counter in some measure the actions of the Whitlam administration, and to remind the Australian government of its obligations towards the South Vietnamese. While Australia discharged its international obligations towards Vietnamese refugees with generosity under the leadership of Malcolm Fraser in the late 1970s and early 1980s, the reverse was the case under Gough Whitlam in 1975.

The deciding factor that separated my family's fate from that of other Vietnamese refugees was the staunch support of senior figures within the Australian administration. The archival record validates the memories of Vietnamese refugees such as Pham Dong Bich regarding the actions of the Australian government in $1975^{70}$ as well as those that were transmitted by my parents. As Trudy Huskamp Peterson suggests, "a person has a right to know what happened, a right to the truth and... society as a whole has both a right to know and a responsibility to remember." ${ }^{71}$ The archives also contextualize the story of my family within the wider narrative of Vietnamese refugees seeking asylum in the aftermath of the war, and the history of Vietnamese settlement in Australia.

In his 2006 lecture on the fall of Saigon, Peter Edwards notes:

We see the irony of a Labor Prime Minister taking a hard line against asylum seekers, while a Liberal opposition leader proclaims his attitude to be hard-hearted and shameful... The Vietnam War in particular had allowed Labor to present itself as the party that best understood world, and especially Asian, affairs. But the refugee issue, and other controversies surrounding the fall of Saigon, removed much of that authority. Now it was the Liberals, led by Malcolm Fraser, a former Minister for the Army and Minister for Defence during the war, who were claiming the moral high ground, while Labor appeared to be politically, diplomatically and morally inept. ${ }^{72}$

70 “The Embassy knew very well that if any Vietnamese personnel working for the Australian Embassy stayed behind, would be imprisoned or persecuted by the new Communist government. But the Embassy evacuated at the order of the Labor government at that time... They did not take anyone except one member, one Vietnamese employee and his wife, because he's in charge of the signals and coded messages, so they could not risk...leaving him behind. And that is documented by Australian journalists; and also documented by the statement made to the Senate Standing Committee on Foreign Affairs and Defence in 1975." Phan Dong Bich, oral history interview, 25 May 1986. NLA TRC 2010 S/86, 16-17.

71 Trudy Huskamp Peterson, “Archives Against Amnesia," Politorbis 50, no. 3 (2010): 126.

72 Edwards, "Fall of Saigon," 15. 
Edwards continues:

A year ago many newspapers devoted extensive space to articles marking the 30th anniversary of the fall of Saigon. What was strikingly different in this coverage, compared with similar exercises in the immediate aftermath of the war, was the impact made by Australians of Vietnamese origin. Individuals, including former diplomats and officers of the former South Vietnamese regime, and their families told their stories, and in the process wove a new strand into the fabric of the Australian national narrative. ${ }^{73}$

I am aware that my family was truly fortunate: we were not in South Vietnam when Saigon fell. And although we became stateless, and lost our country and our home, we were supported through this difficult time by Japanese friends who housed us, cared for us, and organized dinners during which guests were asked to contribute money for our family. We were spared the chaos of the final months, and the final days, of South Vietnam, during which so many died. My parents stressed that we were luckier than most, and while this is undoubtedly true, their attitude also led to the suppression and silencing of the grief that 1975 caused. It is a grief that has underlain our lives since then, and that weighed on my father until his death in 2013, and I think it is a grief that is seldom spoken of between the generations in the Vietnamese community overseas. The Vietnamese have in the main settled successfully in Australia, but this has not been without great cost, even if this cost is not necessarily visible.

The Manuscripts Collection at the National Library and the documents in the National Archives reveal individual Australians who reacted strongly to the perceived lapses in responsibility displayed by the Australian government of the time, and whose support extended beyond those early years to encompass the resettlement of Vietnamese refugees over the next two decades. Their voices may not be many, but they are no less potent for that. Archival research enables access to such voices and in doing so contributes to a fuller knowledge of past events.

As for my family, and the circumstances of our arrival in Australia, I think back to the senior public servants who handled our fates, and who have left these records in the archives. I thank them for displaying charity and generosity at a time when their own government was disinclined to do so. In a large bureaucracy, it can be difficult to remember how closely documents may relate to people and people's lives. In the words of Christopher Fry, "We will discuss you, till you're nothing but words." This process of de-personalization may reflect aspects of bureaucratic decision-making in relation to individual lives. This was not the case, however, with the senior public servants that I have referred to. Their writings attest to the fact that they were only too aware that they were dealing with human lives in the chaos and aftermath of the fall of Saigon. As the archival record and my family history reveal, the actions of senior bureaucrats can and do have immediate repercussions on the lives of individuals and their families. Of them all, Geoffrey Price faced the most difficult choice. As head of mission, he was responsible for all embassy staff, and he knew the dangers facing his Vietnamese staff. He had interceded

Christopher Fry, A Phoenix Too Frequent (London: Hollis \& Carter, 1946), 47. 
on their behalf and asked for permission to bring them to Australia, permission that was denied. And although in the end he obeyed his government's instructions, he was to suffer the consequences of this decision until the end of his life. His moral dilemma was the hardest to bear, and regret can be the most corrosive of emotions. I wonder about the traces all of us leave of our work, our decisions, our impact on the lives of others, the legacy we leave behind us, and the ways in which our words can be interpreted many years later.

Nathalie Huynh Chau Nguyen

Associate Professor and Australian Research Council Future Fellow

National Centre for Australian Studies

Monash University, Australia

nathalie.nguyen@monash.edu 